\title{
INVESTIGATION AND COMPARISON OF G6PD ENZYME SCREENING TEST COSTS FOR ALL NEWBORNS WITH TREATMENT COSTS OF PATIENTS WITH FAVISM ADMITTED DUE TO HEMOLYSIS
}

\author{
Morteza Sadinejad', Hamed Motevali Pour², Saeed Yousefian' ${ }^{3}$, Roham Nik Khah 4 \\ IIsfahan University of Medical Sciences, Department of Pediatrics, Isfahan, Iran \\ 2Isfahan University of Medical Sciences, School of Medicine, Medical Student Research Committee, Isfahan, Iran \\ 3 Isfahan University of Medical Sciences, Children and Adolescent Health Research Center, Isfahan, Iran \\ ${ }^{4}$ Hormozgan University of Medical Sciences, School of Medicine, Medical Student Research Committee, Bandar Abbas, Iran

\section{ISPITIVANJE I UPOREĐIVANJE TROŠKOVA G6PD ENZIMSKOG SKRINING TESTA ZA NOVOROĐENU DECU U ODNOSU NA TROŠKOVE LEČENJA PACIJENATA SA FAVIZMOM HOSPITALIZOVANIH USLED HEMOLIZE}

\author{
Morteza Sadinejad', Hamed Motevali Pur², Said Yusefian³, Roham Nik Kah4 \\ 'Univerzitet medicinskih nauka Isfahan, Katedra za pedijatriju, Isfahan, Iran \\ ${ }^{2}$ Univerzitet medicinskih nauka Isfahan, Medicinski fakultet, Isfahan, Iran \\ ${ }^{3}$ Univerzitet medicinskih nauka Isfahan, Centar za istraživanje zdravlja dece $i$ adolescenata, Isfahan, Iran \\ 4 Univerzitet medicinskih nauka Hormozgan, Medicinski fakultet, Bandar Abas, Iran
}

\begin{abstract}
Objective. We compared the glucose-6-phosphate dehydrogenase (G6PD) deficiency screening costs in neonates and treatment costs for patients with favism who were referred to the government hospitals of Isfahan with acute hemolysis.

Methods. In this retrospective study, 116 patients with favism were selected, and their clinical data and treatment costs were recorded in Iranian Rials (IRR) and United States Dollars (USD). The costs of neonatal G6PD screening tests were estimated based on quantitative and qualitative screening kits by referring to each hospital's laboratories. Approximately 84760 births occurred in Isfahan province from October 2014 to October 2015.

Results. Based on our results, 73 patients (62.9\%) were males, and 43 of them (37.1\%) were females. The causes for hemolysis were the consumption of broad beans in $78.4 \%$, infection in 19.8\%, and drugs (erythromycin and sodium cephalothin) in $1.7 \%$ of patients. The majority of patients (46.6\%) received a single blood transfusion, and 18.9\% received two or more transfusions, while $34.5 \%$ had received no blood transfusions. The mean and standard deviation of patients' medical expenses were 7,472,005 7,329,847 IRR (276.74 271.47 USD). The total cost of treatment for patients was 869,162,324 IRR (32,191.19 USD). The screening cost for all newborns from October 2014 to October 2015 with qualitative kits was 754,364,000 IRR (27,939.40 USD) and with the quantitative kits was 960,330,800 IRR (35,567.80 USD).

Conclusion. The costs of the qualitative screening test for $G 6 P D$ deficiency are lower than the costs of treatments of favism patients in Isfahan.
\end{abstract}

Key words: hemolysis; glucosephosphate dehydrogenase; neonatal screening; favism; health care costs

\section{SA ŽETAK}

Cilj. Uporedili smo troškove skrininga nedostatka glukoze-6-fosfat dehidrogenaze (G6PD) kod novorođenčadi i troškove lečenja pacijenata sa favizmom koji su sa akutnom hemolizom upućeni u državne bolnice u Isfahanu.

Metode. U ovoj retrospektivnoj studiji odabrano je 116 pacijenata sa favizmom, a njihovi klinički podaci i troškovi lečenja evidentirani su u iranskim rialima (IRR) $i$ američkim dolarima (USD). Troškovi neonatalnih skrining testova G6PD procenjeni su na osnovu kvantitativnih i kvalitativnih kompleta za skrining pozivanjem na laboratorije svake bolnice. Otprilike 84.760 porođaja dogodilo se u provinciji Isfahan od oktobra 2014. do oktobra 2015. godine.

Rezultati. Na osnovu naših rezultata, 73 pacijenta (62,9\%) bili su muškarci, a 43 od njih $(37,1 \%)$ žene. Uzroci hemolize bili su konzumacija širokog pasulja kod 78,4\%, infekcije kod 19,8\% i lekova (eritromicin i natrijum cefalotin) kod 1,7\% pacijenata. Vecina pacijenata (46,6\%) primila je jednu transfuziju krvi, a 18,9\% je primilo dve ili više transfuzija, dok 34,5\% nije primilo nikakvu transfuziju krvi. Srednja $i$ standardna devijacija medicinskih troškova pacijenata iznosila je 7.472.005 \pm 7.329.847 IRR (276,74 \pm 271,47 USD). Ukupni troškovi lečenja pacijenata iznosili su 869.162.324 IRR (32.191,19 USD). Troškovi skrininga za svu novorođenčad od oktobra 2014. do oktobra 2015. sa kvalitativnim kompletima iznosili su 754.364.000 IRR (27.939,40 USD), a sa kvantitativnim kompletima 960.330.800 IRR (35.567,80 USD).

Zaključak. Troškovi kvalitativnog skrining testa za nedostatak G6PD niži su od troškova lečenja pacijenata sa favizmom u Isfahanu.

Ključne reči: hemoliza; glukozofosfatna dehidrogenaza; neonatalni skrining; favizam; troškovi zdravstvene zaštite 


\section{INTRODUCTION}

Glucose-6 phosphate dehydrogenase (G6PD) is an enzyme found in the intracellular cytoplasm of humans that conserves cells from the threats of reactive oxygen species by facilitating the regeneration of the intracellular NADP + (1). The G6PD deficiency, also known as favism disease, is the most commonly encountered enzyme deficiency worldwide. With up to 400 mutations detected by 1988, G6PD deficiency is considered the most prevailed enzyme deficiency in humans and approximately affects about 400 million individuals globally $(2,3)$. This $\mathrm{X}$-linked disorder's prevalence is estimated to be about $7.6 \%$ in Iran, making it a remarkable genetic problem (4). The prevalence of favism in Isfahan was $3.2 \%$, of which $1.5 \%$ was for the boy and $1 \%$ for the girl infants $(4,5)$. Neonatal jaundice and acute hemolysis may be commonly manifested due to G6PD deficiency, but children with G6PD deficiency are usually asymptomatic $(2,6)$. Consuming particular foods such as broad beans (Vicia faba), infections, and taking specific drugs such as acetaminophen might lead to hemolytic reactions in the G6PD-deficient patients (7-9). Treating G6PD deficiency in newborns is necessary to prevent the complications of jaundice and the development of kernicterus, and controlling jaundice with phototherapy usually demonstrates significant effects (10). In children and older individuals, the supportive treatment accompanying the prevention of contact with hemolyticinducing agents is typically adequate. Still, in severe hemolysis, the patient may need to receive the packed red blood cell transfusion (3). Quantitative and qualitative laboratory tests used to screen for G6PD deficiency have shown good sensitivity and specificity in various studies $(11,12)$. In Iran, according to the national guidelines, a fluorescent spot test (FST) is performed to screen for the deficiency of the G6PD enzyme, which is an easy, inexpensive, and affordable method in this regard (12).

The prevalence of G6PD deficiency in Iran and a significant number of favism patients who refer to clinics due to acute hemolysis make it necessary to consider specialized patient care. Identification of the neonates with favism through G6PD deficiency screening might be useful in presenting proper patient care to reduce the favism perils and becoming more prepared to deal with the favism-associated complications and managing them optimally. Despite the World Health Organization (WHO) recommendation that G6PD screening is necessary for countries in which the prevalence of G6PD deficiency is more than $3-5 \%$ in males, screening might not be sufficient in many parts of Iran $(2,13)$. Considering these limitations and the lack of similar studies in this field, especially in Iran, we aimed to determine and compare the costs of G6PD deficiency screening in neonates with the costs of treatment for G6PD-deficient patients who referred to Isfahan hospitals with acute hemolysis. Supposing that the screening prices are lower than the costs of treatment, we might have to consider that all newborns should be screened for G6PD since the timely diagnosis of this disorder will bring lower material and spiritual costs to the families of G6PD-deficient patients.

\section{MATERIALS AND METHODS}

This investigation is a retrospective cross-sectional study to determine and compare the costs of screening for G6PD deficiency in newborns with treatment costs for patients with favism who have been diagnosed with acute hemolysis and had been admitted to governmental hospitals with a specialized children's department in Isfahan city (including Imam Hossein, Amin, Gharazi and Shariati hospitals) from October 2014 to October 2015. The sampling method was a census in this study. The inclusion criteria included all children who had been diagnosed with G6PD deficiency as the final diagnosis at the time of their discharge from the hospital. Exclusion criteria involved hemolysis for reasons other than G6PD deficiency and the presence of patients' records with more than $20 \%$ of defects.

Based on the inclusion and exclusion criteria and considering the census sampling settings, 116 individuals were enrolled within the study period. The Iranian National Organization for Civil Registration office in Isfahan stated that there had been 84760 births in Isfahan province from October 2014 to October 2015. To estimate G6PD deficiency screening costs, we referred to the laboratories of the study hospitals. By asking the relevant authorities, it was revealed that the screening costs were based on the guidelines for screening methods and fees for each infant, which included hospital services (such as costs of drawing blood samples, syringe, tape, etc.) and the prices of qualitative screening kit (50 individual tests per kits crafted by Kymia Pajohan Research \& Manufacturing Co. for 390,000 Iranian Rials or IRR, or 14.44 United States Dollars or USD) which was estimated to be 8900 IRR ( 33 Cents) per child. Previous studies had shown that the sensitivity and specificity of the kit mentioned above is $99 \%$ (12). To obtain the clinical data and treatment costs of study patients, we referred to each hospital's financial department. We recorded the costs of all the patient's services and the costs of providing packed red blood cells. We recorded the information into a computer for further evaluation. We analyzed our data using IBM SPSS Statistics for Windows version 24.0 software, Armonk, NY: IBM Corp. Qualitative information was expressed in terms of numbers and percentages, and quantitative data were described in terms of mean and standard deviation and displayed in the table. 


\section{RESULTS}

In this research, we studied 116 patients with an age range of 1 month and 38 years with G6PD deficiency who were admitted due to the presence of acute hemolysis of whom, 73 were male (62.9\%), and 43 were female (37.1\%). Patients' median age was three years and four months, and the interquartile range was to 2 to 5 years. The minimum and maximum hospitalization duration were one and 22 days respectively, with a mean and standard deviation of $2.95 \pm 2.10$ days. In this study, the leading causes of hemolysis manifestation in G6PD deficiency were broad beans in $78.4 \%$, infection in $19.8 \%$, and medication (Erythromycin and Sodium Cephalothin) in $1.7 \%$ of the patients. The mean and standard deviation of the frequency of packed red blood cell transfusion were $0.88 \pm 0.8$ (range $0-4$ ), and the frequency of admission was $1.16 \pm 0.58$ (range $1-5$ ). $46.6 \%$ of patients received one, and $18.9 \%$ received two or more packed red blood cell transfusions, while $34.5 \%$ had no transfusions. Most patients $(90.5 \%)$ had been admitted once, and only $9.5 \%$ had been admitted more than once. Numerical indices of hemolytic agent exposure are shown in table 1.

It was found that $23.3 \%$ of patients lived in the eastern, $32.8 \%$ in the western, $23.2 \%$ in the southern, and $20.7 \%$ in the northern region of Isfahan city. The mean and standard deviation of patients' medical expenses were 7,472,005 \pm $7,329,847$ IRR (276.74 \pm 271.47 USD). The lowest cost of treatment in patients was 217,220 IRR (8.04 USD), the highest was $65,189,452$ IRR (2,414.42 USD), and the total patient care costs were equal to $850,262,222$ IRR (31,493.2 USD). The estimated screening cost for the total births from October 2014 to October 2015 was $754,364,000$ IRR (27,940 USD) and for quantitative kits was $960,330,800$ IRR $(35,567.80$ USD).

\section{DISCUSSION}

Our results revealed that patients' medical costs were approximately 850 million IRR (31,482 USD), while the estimated costs of G6PD deficiency screening were nearly 750 million IRR (27,778 USD). Therefore, in Isfahan, screening is cheaper than the treatment costs. It's noteworthy that although many insurance companies in Iran cover the expenses of some health care products such as packed red blood cells, ultimately, its costs affect the financial aspects of the health care system. In Iran, the price per unit of packed red blood cell in 2014 ranged from 1.5 million to 50 million IRR (55.55 to 1,852 USD) (rare blood groups), and the average processing cost per unit of packed blood cell was about 100 USD globally (the value of one USD varied between 26,670 to 29,960 IRR from October 2014 to October $2015 \mathrm{https}$ ://www.cbi.ir/ exrates/rates_en.aspx) (13-15). In our study, the cost of each packed red blood cell unit was estimated at an average of one million and 350 thousand IRR (50 USD) by inquiring the hospital's blood transfusion unit, which was less than the reported figures. It is difficult to calculate the cost of each unit of packed red blood cell at different times in Iran due to dynamic economic status (according to the financial year, the mean of 27,000 IRR in exchange for one USD was considered throughout the study).

On the other hand, as we consider the probable cases of the rare blood groups, one might suppose that subsequently, the final costs of treatment might have been underestimated. Nevertheless, even without considering the above, the screening method used in the country is less costly compared to the treatment costs in hospitals. In a study by Darbandi et al. from 2011 to 2012,110 patients with favism were evaluated, most aged 2-4 years, and were mainly males. The treatment costs in their study were higher than the screening costs, considering the price of packed red blood cell transfusions. In their research, the estimated packed red blood cell cost was based on the global benchmark for each packed red blood cell unit, but in any case, their results were similar to our findings (15). These results are consistent with the findings of the study by Hatam et al. conducted in Shiraz. In their research, the cost-effectiveness of screening for phenylketonuria, congenital hypothyroidism, and G6PD deficiency and the treatment costs for each of these disorders were evaluated. Afterwards, the authors suggested that screening was economically superior to the treatment costs followed by the late diagnosis (16).

It should be noted that apart from the patients' treatment costs, some of the problems that patients with G6PD deficiency endure (such as emotional disturbances, family stress, the development of diseases such as renal dysfunction, seizure, etc.) might be indirect costs. As a result, the screening will be much wiser considering the above. Many patients who are not diagnosed during infancy due to lack of symptoms may refer to a doctor at an older age, but in the absence of severe symptoms, many might not need to be hospitalized and could be managed in an outpatient setting. Therefore, the cost of visits, laboratory tests, and other expenditures creates problems for families.

Table 1. Numerical indices of hemolytic agent exposure

\begin{tabular}{|l|c|c|c|c|c|c|}
\hline Agent & Number & Mean & Standard deviation & Median & Minimum & Maximum \\
\hline Broad beans & 91 & 1.10 & 0.53 & 1 & 1 & 5 \\
\hline Infection & 23 & 1.39 & 0.72 & 1 & 1 & 4 \\
\hline Medication(s) & 2 & 1 & n.a. & 1 & 1 & 1 \\
\hline
\end{tabular}

n.a.-not applicable 
On the other hand, in the present study and other similar investigations, these individuals are not included in the hospitalized group, and the overhead costs are not included in the final treatment costs' evaluation. Hence, identifying patients with screening helps to enhance the therapeutic system to deal with the complications in patients with favism, and early management of these patients could effectively reduce the rate of hospitalization, and subsequently, the cost of treatment. Although we did not explore this issue in our study, similar studies have presented consistent results with the hypothesis mentioned above. A survey by Cohan et al. investigated the cost-effectiveness of screening for the deficiency of the G6PD deficiency in southern Iran. They evaluated the incidence of hemolysis in patients with favism before and after implementing the national program for G6PD deficiency screening and suggested that after screening, the rate of hospitalization was significantly reduced, and therefore screening program was cost-effective (17).

These results are consistent with the findings of the study by Khneisser et al., who found that by screening for G6PD deficiency, the hospitalization rate for patients with Favism was 95\% lower compared to those who had not been screened, and therefore screening program has proven effective in this regard (18). One crucial point is that screening might reduce the hospitalization rate to zero because of the false negative or positive results, and therefore the need for re-testing (at least twice) is recommended (17). This fact, in addition to increased parental knowledge about hemolytic attacks, could prove more effective in reducing hospitalization rates, although comparing and analyzing screening and treatment costs, in this case, requires consideration of both screened and nonscreened groups, which was out of the format of this study.

One of the most important limitations of our study is the relatively low sample size, which naturally makes generalizing the results to the whole society more complicated. Besides, our study hospitals provide their screening kits from particular contractors, while some other companies' costs may be lower at some intervals. On the other hand, many asymptomatic G6PD-deficient individuals may not refer to the hospital, are not diagnosed, and, as a result, are not involved in the study. Evaluations in this field are limited, and considering that the prevalence of this disorder varies in different parts of Iran and some regions, there is a higher prevalence of favism, the cost-effectiveness of G6PD deficiency might be more tangible (4). Therefore, it is advisable to carry out more extensive research with a larger sample size considering different races and regions of the country in the future to assess better the costs of screening and treatment in the G6PD deficiency and their differences.
In conclusion, the cost of screening for G6PD deficiency is lower than that of patients' treatment costs in Isfahan and is therefore recommended to help patients encounter fewer socioeconomic complications of favism.

\section{ACKNOWLEDGMENT}

We dedicate this paper to the memory of our dear colleague Dr. Mohammad Reza Mohammad Hoseini Isini, who passed away while this paper was being peerreviewed. Dr Mohammad Hoseini has been a great friend and a very talented physician who greatly helped us in the analytic process and documentations. The paper has been prepared based on a medical doctoral thesis that was approved by the Vice-Chancellor for Research of the School of Medicine in Isfahan with the registration number 395397.

\section{CONFLICT OF INTEREST}

The authors declare that there is no conflict of interest regarding the publication of this paper.

\section{ABBREVIATIONS}

FST-fluorescent spot test

G6PD-glucose-6-phosphate dehydrogenase

IRR-Iranian Rials

USD-United States Dollars

WHO-World Health Organization

\section{REFERENCES}

1. Ley B, Bancone G, von Seidlein L, et al. Methods for the field evaluation of quantitative G6PD diagnostics: a review. Malar J 2017; 16: 361.

2. Elella SA, Tawfik M, Barseem N, Moustafa W. Prevalence of glucose-6-phosphate dehydrogenase deficiency in neonates in Egypt. Ann Saudi Med 2017; 37: 362-5.

3. Bubp J, Jen M, Matuszewski K. Caring for glucose-6phosphate dehydrogenase (G6PD)-deficient patients: implications for pharmacy. PT 2015; 40: 572-4.

4. Moosazadeh M, Amiresmaili M, Aliramezany M. Prevalence of G6PD deficiency in Iran, a metaanalysis. Acta Med Iran 2014; 52: 256-64.

5. Iranpour R, Hashemipour M, Talaei SM, Soroshnia M, Amini A. Newborn screening for glucose-6-phosphate dehydrogenase deficiency in Isfahan, Iran: a quantitative assay. J Med Screen 2008; 15: 62-4.

6. Beutler E. Glucose-6-phosphate dehydrogenase deficiency: a historical perspective. Blood 2008; 111: 16-24. 
7. Luzzatto L, Seneca E. G6PD deficiency: a classic example of pharmacogenetics with on-going clinical implications. Br J Haematol 2014; 164: 469-80.

8. Espino FE, Bibit JA, Sornillo JB, Tan A, von Seidlein L, Ley B. Comparison of three screening test kits for G6PD enzyme deficiency: implications for its use in the radical cure of vivax malaria in remote and resource-poor areas in the Philippines. PLoS One 2016; 11: e0148172.

9. Greer JP, Rodgers GM, Glader B, Wintrobe MM. Wintrobe's clinical hematology. 14th ed. Philadelphia, Baltimore, New York: Wolters Kluwer, 2019.

10. Liu H, Liu W, Tang X, Wang T. Association between G6PD deficiency and hyperbilirubinemia in neonates: a meta-analysis. Pediatr Hematol Oncol 2015; 32(2): 92-8.

11. LaRue N, Kahn M, Murray M, et al. Comparison of quantitative and qualitative tests for glucose-6phosphate dehydrogenase deficiency. Am J Trop Med Hyg 2014; 91: 854-61.

12. Kosaryan M, Mahdavi MR, Jalali H, Roshan P. Why does the Iranian national program of screening newborns for G6PD enzyme deficiency miss a large number of affected infants? Pediatr Hematol Oncol 2014; 31: 95-100.
13. Vatankhah S, Jalilvand M, Sarkhosh S, Azarmi M, Mohseni M. Prevalence of congenital anomalies in Iran: a review article. Iran J Public Health 2017; 46: 733-43.

14. Rezaie M, Khaleghian A. Blood and blood product utilization and causes of wastage in Semnan hospitals. J Mazandaran Univ Med Sci 2016; 26: 247-8.

15. Darbandi B, Noghbaei M, Mehrabian F, Jafroodi M. Medical expenses of patients with Favism admitted to 17th Shahrivar Hospital compared to G6PD enzyme screening cost, in north of Iran. Iran J Ped Hematol Oncol 2014; 4: 53-6.

16. Hatam N, Shirvani S, Javanbakht M, Askarian M, Rastegar M. Cost-utility analysis of neonatal screening program, Shiraz university of medical sciences, Shiraz, Iran, 2010. Iran J Pediatr 2013; 23: 493-500.

17. Cohan N, Karimi M, Khalili AH, Falahzadeh MH, Samadi B, Mahdavi RM. The efficacy of a neonatal screening programme in decreasing the hospitalization rate of patients with G6PD deficiency in southern Iran. J Med Screen 2010; 17: 66-7.

18. Khneisser I, Adib SM, Loiselet J, Megarbane A. Costbenefit analysis of G6PD screening in Lebanese newborn males. J Med Liban 2007; 55: 129-32. 